DOI https://doi.org/10.18551/rjoas.2018-09.53

\title{
HUMAN RESOURCE SCORECARD: A MODEL OF HUMAN RESOURCE PERFORMANCE MEASUREMENT
}

\author{
Fariz*, Winarsih Tutik \\ Yapan Surabaya College of Economics, Indonesia \\ *E-mail: fariz@stieyapan.ac.id
}

\begin{abstract}
Professionals in the field of human resource always face external and internal challenges so that they need a strategic perspective that is in accordance with their role in the organization. As professionals, they need to answer the challenges through one approach of human resource performance measurement and are required to know the contribution of human resource to organizational performance. In this matter, this approach is the theme concerned in human resource scorecard.
\end{abstract}

\section{KEY WORDS}

Human resource, scorecard, performance, challenge.

The concept of "Balance Scorecard" for organizational performance measurement was introduced in one of the books written by Kaplan and Norton in 1992. Since that, Kaplan and Norton have developed the concept of "Balance Scorecard" for \pm 200 companies in America. One of the questions that were always asked when they were designing the concept is "what is your organizational strategy?" Through such question, Kaplan and Norton were inspired to understand how the leaders of the organization think about his/her organization. In most cases, the leaders of the organization have similarities especially in focusing the financial strategy and in delivering the priority to the operational improvement process. It is believed that organizational leaders do not pay attention to customer strategy (who the target is; the values applied in the organization). They do not seem to realize and understand the importance of strategy for human resource development (Human Capital).

In the current organization and new economic development, particularly in value creation, an organization is strongly dominated by "human capital" and other "intangible capital". Therefore, it is necessary to measure the HR strategy. One of the concepts introduced in this measurement is "HR scorecard" which offers several important steps to be used in HR strategy management.

However, the concept is not easy to apply considering that HR is the main driver of company strategy. In connection with that, the framework of this study is: the second part will describe the HR architecture as a strategic capital while the third part will review the steps to realized HR scorecard and then, in the fourth part, the dimensions of HR performance measurement will be explained with HR scorecard. The cover will be presented in the last part of this study.

HR Architecture as Strategic Capital. According to Becker, Huselid and Ulrich (2001), an effective system of HR measurement has 2 (two) important objectives namely: (1) providing instructions for decision-making in the organization, and (2) serving as a basis for HR performance evaluation. The concept developed in the HR Scorecard is aimed at the important roles of HR professionals henceforward.

If the focus of the company's strategy is to create a sustainable "competitive advantage", then the focus of the HR strategy must be adjusted. This is to maximize the HR contribution towards organizational goals which further creates a value for the organization. The basis of HR strategic role consists of a 3-dimensional value chain developed by a company's HR Architecture such as function, system, and behavior of the employees.

In detail, the term "Architecture" explains HR profession within the function and system of $\mathrm{HR}$ related to its policies and practices through competence, motivation, and behavior. 
This following Figure 1 illustrates the process of HR strategy architecture (Becker, Huselid and Ulrich, 2001).

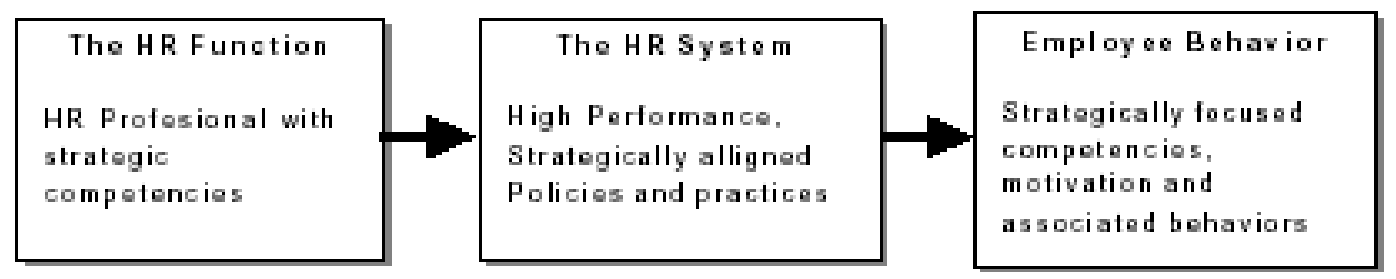

Figure 1 - HR Strategy Architecture

Human Resources Function. The basis for the creation of HR strategy values is managing the infrastructure to understand and implement company strategies. Usually, HR professionals are expected to direct this effort. Huselid, Jackson, and Randal (in Becker, Huselid \& Ulrich, 2001) revealed that the effective human resources management consists of 2 important dimensions, namely:

- Technical HR Management, including recruitment, compensation, and benefits;

- Strategic HR Management, including delivering the service of Technical HR management in a direct effort which supports the implementation of company strategies.

Huselid et al., (2001) found that most HR managers tend to focus on traditional delivery activities or technical HR Management activities and pay less attention to the dimension of strategic HR management. The competencies that need to be developed for the future HR Managers which have a huge influence on organizational performance is Strategic and Business HR Management Competencies.

Human Resources System. The HR system is the main element that is influential in strategic human resources. This system model is called 'High-Performance Work System' (HPWS). In HPWS, every element in the HR system is designed to maximize all human capital quality through such an organization. The function of HPWS to build and maintain the supply of human capital quality is:

- To connect the selection and promotion to validate the competency model;

- To develop the strategy which provides effective time and support for the skill demanded in the implementation of organizational strategy;

- To carry out an interesting compensation policy and performance management as well as to maintain and motivate high employee performance.

Those are the important steps in the decision-making of employee quality improvement so that the organization will be possible to make a good organizational performance. To make an HR able to create a value, the organization needs to create a structure for every element of the HR system by emphasizing, supporting, and reinforcing HPWS. However, it will be not enough if only adopting a performance which focuses on HR policies and practices. In an essence, it needs a system that emphasizes the "interrelationship" between HR system components as well as the relationship between HR and wider strategy implementation.

HPWS directly creates 'customer-value' and other related value. In this case, the alignment process starts when the HR clearly understand the chain of company value; a solid understanding of the company's values and how it was created. The key to this matter is that the characteristics of HPWS not only adopt the right HR policies and practices but also the way to manage HR practices. In HPWS, HR policies and practices show a strong alignment (partnership) with operational goals and competitive strategies of the organization. Each HPWS in an organization is different from one another so that it can be adjusted with its own uniqueness, strengths, and needs of each organization.

Strategic Employee Behavior. The strategic role of HR or the "human capital" might focus on the productivity of employee behavior in the organization. Strategic behavior is a 
productive behavior implementing organizational strategies at the same time. This strategy consists of 2 (two) general categories such as:

- Core behavior is a plot that comes directly from core behavior competencies defined by the organization. This is very fundamental for organizational success;

- Situational specific behavior that is essential as a key point in an organization or as a value chain in a business. For example, it can be in the form of cross-selling skills needed by a branch of a bank.

Integrating the attention on behavior into the whole business to influence and measure HR contribution to the organization is a challenge. Which one is the important thing? And how do they manage it? First, the importance of the behavior will be defined by the interests of organizational strategy implementation. Secondly, it is important to remember that we do not influence the strategic behavior directly but that the behavior is a result of the HR architecture broad.

Several Steps to Implement the HR Scorecard. In the implementation of an HR scorecard, there are 7 (seven) steps to transform the HR architecture into a strategic model. The question in this matter is about how the HR can be formalized into a strategic role. According to Becker, Huselid, and Ulrich (2001), how they connect their functions into the strategic organizational implementation needs to be illustrated. The steps taken in the strategic HR implementation are described in the following section:

Clearly Define the Business Strategy. It is suggested to also focus on the strategy implementation rather than just focusing on the content of the strategy so that the senior HR leaders can facilitate the discussion about how to communicate the company goals through an organization. The strategic goal should not be vague meaning that it is able to increase operational cost efficiency, increase international market presence, and improve productivity. If not formulated clearly and firmly, this strategy will be confusing for the employees making them unable to find out the action that needs to be done in reaching the goal. Consequently, the organizational strategy must be clear and formed in detail terms so that it can be implemented.

Build a Business Case for HR as A Strategic Asset). After the company clarifies the strategy, HR professionals need to build a business case to find out why and how HR can support organizational strategy. In making business cases, they need to conduct a research to support the recommendation in such case formulation: The results showed that the success or failure of a company is determined by the way they implement its effective strategy and not the content of the strategy.

Create a Strategy Map. A company needs to have a clear organizational strategy in establishing the steps of strategy implementation. In most organization, customer value included in the products and services is seen as a complex result and cumulative process that is called as "value chain" by Michael Porter. All organizations have "value chain" even though it has not been articulated yet. Every system of organizational performance measurement must pay attention to every relationship in the chain.

To define the process of "value creation" in an organization, it is recommended that the top and medium managers, who will implement the company strategy, build a strategy map which represents the value chain of the organization. To start the mapping process, the company needs to analyze the objectives of the company strategy by asking these following questions:

- Which is the important strategic objectives/target/outcome?

- What is the Performance Driver of each objective?

- How do we measure each progress to guarantee that we achieve the objective?

- What are the obstacles to achieving each objective?

- What efforts that employees need to do to achieve this objective?

- Does the HR provide competent employees and behavior to achieve that objective?

- If not, does it need a change?

The above questions can provide information on how far the HR contributes to the success of the company. It is recommended that the question is also equipped with other 
information such as making a questionnaire to test whether the employees understand the company goals or not and having a survey to ask about Performance Drivers and company capability.

Identify HR Deliverables within the Strategy Map. As mentioned in the previous description, HR created its values at the meeting point between the systems of strategy implementation. Maximizing the value requires an understanding from various interconnected sides. If the HR Manager does not understand the business aspects, the other managers will not appreciate the HR section. Therefore, the HR Manager is responsible to establish HR Deliverables which are: HR Performance Driver and HR Enabler on the Strategy Map.

In this case, HR Manager is required to set the suitable HR Deliverables which can support the company performance as specified in the Strategy Map and focus on the strategic behavior to enhance the competency, reward, and task of the organization. As for examples: the company decided that employee stability or low turnover (enables) can increase the life cycle of the R\&D section (high-performance driver). With this relationship, company policies can be formed such as increasing salaries and bonuses which can retain experienced R\&D employees.

Align the HR Architecture with HR Deliverables. The next step is to design an HR system (rewards, competencies, organizational tasks, and so on) which can support HR Deliverables. The misalignment between the HR system and the implementation of the strategy can destroy the value which has been set.

Design the Strategic HR Measurement System. In this stage, it does not only need a new perspective on HR performance measurement, but also resolutions from some technical things that are not known by many HR professionals. To measure HR relations with company performance, valid HR Deliverable measurements are needed, such as:

Make sure that the right HR Performance Driver and HR Enabler are chosen. This requires a clear understanding on the chain of causes of effective company strategy implementation.

Choose the right measurement to measure the HR Deliverable. As for examples: HR Deliverable is the stability of senior employees, but there are several ways to measure this concept. The measurement development requires the right definition of whobecame the senior staff (employees who have 5 to 15 years of experience) and what is meant by employee stability. Is the stability include all employee turnover or only partially? Is it including the individual employees who have been promoted before?

After the HR Scorecard was developed based on the principles described in the model, it generates a "powerful" management tool. In fact, implementing this tool is nothing more than "keeping the score" of HR influence on performance company. If the HR Scorecard is aligned with the importance of the company's strategy, HR professionals will find new insights about what to do to manage HR as strategic assets. Performing the new management process that based on step 1 until step 6 requires a change and flexibility. Furthermore, this process is not only done once. HR professionals must regularly review the HR Deliverables to ensure that the driver and enabler are still considered significant.

The important elements of the HR Scorecard are HR Deliverable identification, HPWS use, HR System Alignment, and HR Efficiency. It reflects the balance between cost control and value creation. Cost control comes from HR Efficiency measurement while value creation comes from HR Deliverable measurement, external HR system alignment, and High-Performance Work System. The last three things above are the important elements of HR Architecture which tracks the value chain from function to the system then into employee behavior.

Because the focus of strategic HR role is creating a value, then thinking about HR Architecture means expanding the views about HR value chain. This is similar with Balanced Scorecard which contains the leading indicators and lagging indicators. HR Scorecard also has the same thing where HPWS and HR System Alignment are the leading indicators and HR Efficiency and HR Deliverables are the lagging indicators.

The Dimensions of HR Performance Measurement using HR Scorecard. The stages of designing the HR measurement system through the HR Scorecard approach are as follows: 
Identifying HR Competency. What is meant by competency, in this case, is in the form of knowledge, skills, ability, and personality characteristics which affect the performance directly? The results of a study on HR competency from Perrin (1990) (in Becker, Huselid \& Ulrich) show that HR competency is identified as:

- Having computer skills(executive line);

- Having an extensive knowledge on the vision for HR (Academic);

- Having the ability to anticipate the effects of change (Consultant);

- Having the ability to provide education about human resources and to influence the line manager (HR Executive).

The measurement of a High-Performance Work System (HPWS) puts the basis to build human resources into strategic assets. It is believed that HPWS can maximize employee performance. Every measurement of HR system must enter a collection of indications which reflects on the 'focus on performance' from each element of the HR system. HPWS measurement focuses more on how the organization works through every HR function starting from a macro level and emphasizes on the performance orientation at each activity.

Measuring HR System Alignment means assessing the extent of the HR system in meeting the needs of company strategy implementation which is known as external alignment. In contrast, what is meant by internal alignment is how each element can work together and not experiencing a conflict. In this case, the internal alignment does not need to be measured because if the HR system is focused on the strategy implementation (external alignment) or able to manage external alignment, the internal alignment tends to not occur. Focusing on internal alignment is appropriate if the company measurement does not adopt strategic HR perspective. The selection of the right alignment measurement will help to understand which HR Deliverable that is needed to create value in the organization. This also determines the elements of leading indicators which must be mutually reinforced to produce HR Deliverable. Certain alignment measurement will be connected directly with certain deliverables in the Scorecard. Connecting this two things will emphasize the causeand-effect relationship to support HR contributions to company performance. To have the right alignment measurement, a company must focus on the elements in the HR system which have a significant contribution to certain HR Deliverables. It is important to note that this will be different for each company. The identification of this measurement requires a combination of HR professional understanding with knowledge on value creation process. The alignment measurement process is a 'top-down' process (based on the Strategy Map) which will be able to identify the HR Deliverables as well as determining which elements of HR system that needs such alignment (no exact standards). It can be in the form of HPWS measurement. The measurement of external HR alignment system is designed to be used in the HR Department.

HR Efficiency portrays the function of HR to help the company in achieving the required competence with an effective cost. It does not mean that the HR must minimize the costs without paying attention to the results or outcome; they reflect the balance. The HR Efficiency measurement consists of two types of categories:

Core efficiency measurement which represents significant HR expenditure and does not contribute directly to the company strategy implementation. This consists of:

- Benefit-cost as a percentage of payroll;

- Worker compensation;

- Right income percentage on the HR information system;

- Strategic efficiency measurement which measures the efficiency of HR activities and processes designed to produce HR Deliverables;

- The cost per person hired;

- The cost per hour of training;

- HR expenditure for employees;

- HR Deliverable.

To integrate HR into a business performance measurement system, managers must identify the things which connect the HR and the strategy implementation plan. It is called 
"Strategic HR Deliverable" that is the outcome of HR Architecture which will implement a company strategy. This is contrary to HR Doables which focuses on HR efficiency and a number of activities.

HR Deliverable consists of:

- HR Performance Driver: the capability or assets related to people (core peoplerelated) which can in the form of employee productivity and job satisfaction.

- Enables Performance Driver: it strengthens the Performance Driver and can be in the form of changes in reward structure allowing the presence of prevention rather than reactive. If a company identifies employee productivity as the core of Performance Driver, it can change into Enabler Performance Driver by doing a re-skilling.

Therefore, the company should focus on the two things above fairly. The company should not only think about the HR which focuses on the matter of enabler in the organization but also on a particular HR Enabler which can strengthen the Performance Drivers in operational terms, customers, and financial segment (non-HR).

HR Deliverable is an important contribution in human capital to implement the company's strategy. Strategically, it focuses on employee behavior like the low turnover. HR Deliverable measurement helps to identify unique causal relationship where the HR system creates value in a company. The right selection of HR Deliverable measurement depends on the place of HR to display the strategy implementation. HR Deliverable can be in the form of organization capability. This capability will combine individual competencies with an organizational system that is able to add value through the company's value chain. Another approach is by focusing on understanding the people-related capabilities such as leadership and organizational flexibility. It is easy to imagine that capability can affect the success of an organization in general.

Ideally, HR Deliverable in HR scorecard includes several measurements of strategic influence from the defined HR Deliverable. This includes estimating the relationship between each HR deliverable with the performance drivers in the Strategy Map. Therefore, it can connect the influence of deliverables through performance drivers and then company performance. The examples of Performance Driver Measurement are the access to business information to speed up the decision-making, the effectiveness of sharing information within departments, the effectiveness of the PA to deal with poor performance, and so on.

\section{CONCLUSION}

HR Scorecard is a new approach in HR performance measurement to improve organizational performance. This measurement model is very important for HR managers to face challenges in the future due to the fact that the environment is always changing.

After learning the HR Scorecard, it is expected that the company provides benefits for $\mathrm{HR}$ professionals to understand the differences between HR Doables (HR performance that does not affect company strategy implementation) and HR Deliverable (HR performance which affects the implementation of company strategy). Besides that, it is anticipated to find and measure the Leading Indicator and Lagging Indicator where a strategic HR model can give a contribution and connect HR decisions and HR systems with HR Deliverable. Later, it will affect the key performance driver in the strategy implementation. Most importantly, HR professionals can effectively manage the strategic responsibility such as focusing on the right decision-making which will affect the implementation of organizational strategy.

For the organizations, this measurement might help to control the cost of value creation in a company. Furthermore, it can be used to assess the HR contributions in strategy implementation as well as to support organizational changes and flexibility.

\section{REFERENCES}

1. Becker, B., Huselid, M., Ulrich, M. 2001. The HR Scorecard: Linking People, Strategy and Performance. From: http://www.worldofhr.com/HR\%20scorecard.pdf 
2. Gilley, J. W., \& Maycunich, A. (2000), The Beyond Learning Organization, NY Perseus Books

3. Mulyadi. (2001), Balance scorecard: alat manajemen kontemporer untuk pelipat ganda kinerja keuangan perusahaan. Penerbit Salemba Empat Jakarta.

4. Porter, M. E. 1985. Competitive Advantage: Creating and Sustaining Superior Performance. US: The Free Press

5. Kaplan R. S. \& Norton, D. P. 2001.The Strategy Focused Organization: How Balanced Scorecard companies thrive in the new business environment. Harvard: Harvard Business School Press.

6. 1996, Using the Balanced Scorecard As A Strategic Management System. Harvard: Harvard Business School Press.

7. Mathis, R. L. \& Jackson, J. H. 2001. Human resources management. Translated by Tim Salemba Empat Jakarta. Jakarta: Penerbit Salemba Empat.

8. Rothwell. J.W., Hohre, K.C. and King, B.S. (2000). Human Performance Improvement: Building Practitioner Competence. Gulf Publishing, Co, Houston, Texas, USA

9. Ulrich, D. 1988. Human Resource Champions: The Next Agenda for Adding Value and Delivering Results. Boston, MA: Harvard Business School Press. 